Article

\title{
Effect of Temperature on Life History and Parasitization Behavior of Trichogramma achaeae Nagaraja and Nagarkatti (Hym.: Trichogrammatidae)
}

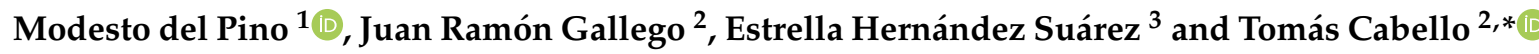 \\ 1 Andalusian Institute for Research and Training in Agriculture, Fishery, Food and Organic \\ Production (IFAPA), Málaga Centre, Cortijo de la Cruz s/n, 29140 Churriana, Málaga, Spain; \\ modesto.pino@juntadeandalucia.es \\ 2 Research Centre for Mediterranean Intensive Agrosystems and Agrifood Biotechnology (CIAMBITAL), \\ Agrifood Campus of International Excellence (CEIA3), University of Almeria, Ctra. de Sacramento, s/n, \\ 04120 La Cañada, Almeria, Spain; jgg436@ual.es \\ 3 Canarian Institute for Agricultural Research (ICIA), P.B. 60, ES 38200 La Laguna, Santa Cruz de Tenerife, \\ Canary Islands, Spain; ehernand@icia.es \\ * Correspondence: tcabello@ual.es; Tel.: +34-950-015-001
}

Received: 8 July 2020; Accepted: 27 July 2020; Published: 29 July 2020

\begin{abstract}
Trichogramma achaeae Nagaraja and Nagarkatti (Hymenoptera: Trichogrammatidae) is currently used as biological control agent for several lepidopteran pests. Knowledge of thermal requirements is essential to optimize its rearing procedures and inundative releases. The biological characteristics and two-sex life table parameters of $T$. achaeae were determined at five constant temperatures (15, 20, 25, 30, and $\left.35^{\circ} \mathrm{C}\right)$ using Ephestia kuehniella Zeller (Lepidoptera: Pyralidae) eggs. T. achaeae was able to develop and survive from $15^{\circ} \mathrm{C}$ to $30^{\circ} \mathrm{C}$, but not at $35^{\circ} \mathrm{C}$. Temperature significantly affected the preadult development time and adult longevity, decreasing when temperature increased from $15^{\circ} \mathrm{C}$ to $30^{\circ} \mathrm{C}$. Temperature significantly altered the sex ratio, being female biased between $15^{\circ} \mathrm{C}$ and $25^{\circ} \mathrm{C}$. Age-stage, two-sex life table analysis indicated that net reproductive rate $\left(R_{0}\right)$ was highest at $20^{\circ} \mathrm{C}$. Both the intrinsic rate of increase $(r)$ and finite rate of increase $(\lambda)$ increased with increasing temperature, while the mean generation time $(T)$ decreased significantly. In addition, functional response of $T$. achaeae was studied, being significantly affected by temperature and host egg density, displaying a Holling type-I at $15^{\circ} \mathrm{C}$ and a Holling type-II at $25^{\circ} \mathrm{C}$. The relevance of these results is discussed for the use of T. achaeae as biological control agent.
\end{abstract}

Keywords: Trichogramma achaeae; Tuta absoluta; Chrysodeixis chalcites; Trichogrammatidae; egg parasitoid; biological control; two-sex life table; functional response

\section{Introduction}

Global trade and climate change have led to an exponential increase in the introduction and establishment of numerous invasive insect pests to new geographic areas, producing substantial ecological and economic impacts [1]. Several non-native Lepidoptera species have been established in Europe in recent years, and some native species have expanded their range within the continent [2]. Among the invasive species, the range of the South American tomato leafminer, Tuta absoluta Meyrick (Lepidoptera: Gelechiidae) has expanded rapidly since its accidental introduction in eastern Spain in 2006 [3]. In a few years, this species has rapidly spread throughout Europe, Africa, the Middle East and parts of Asia, becoming a devastating pest to tomato production worldwide [3-5]. Besides, due to climate change, many moth pest species are changing their migration routes from North Africa or southern Europe, invading new geographical areas where they can optimally reproduce and survive [6]. 
In this sense, the golden twin-spot moth or tomato looper, Chrysodeixis chalcites (Esper) (Lepidoptera: Noctuidae) is an extremely polyphagous species that has increased its movement and spread within central and northern Europe, causing severe damage to horticultural and ornamental crops both in open fields and in greenhouses [7], which indicates its potential expansion to other areas globally [8].

The appearance of lepidopteran pests in newly invaded areas has been predominantly managed by extensive application of broad-spectrum and persistent insecticides [5,9], which have often proved rapidly ineffective due to the development of resistance [10] and a multitude of undesired side effects on non-target organisms [11,12]. Thus, development of integrated pest management (IPM) programs is needed to attempt minimize the damage caused by these pests below the economic injury levels, reducing consequently the use of insecticides [13].

Among these strategies, inundative biological control with egg parasitoids of the genus Trichogramma (Hymenoptera: Trichogrammatidae) has shown efficient results in controlling several lepidopteran pests in many agricultural crops and forests worldwide [3,14,15]. These parasitoids can be inexpensively produced in large numbers and easily released in fields or greenhouses [16], reducing both egg hatching and subsequent crop damage caused by larval feeding [14], thus restricting the application of pesticides and contributing to the conservation of environment and human health [17]. Trichogramma achaeae Nagaraja and Nagarkatti have been reported as a potential biological agent for controlling T. absoluta and C. chalcites eggs in the Palearctic region [18]. It is a generalist and arrhenotokous species originating from India, which parasitizes the eggs of 26 lepidopteran species belonging to 10 different families [19], but it currently has extensive worldwide distribution due to its possible accidental or voluntary dispersion [18]. This parasitoid has been purposefully introduced for the biological control of lepidopteran pests to various European, African, South and Central American countries [3,18] and has been recently recorded on Hawaii [20] and the Canary Islands [18,21]. In addition, T. achaeae is currently commercialized and used in some European and North African countries against different Lepidoptera species in more than 15 horticultural and ornamental crops [3,22]. Indeed, T. achaeae has been shown to be a highly efficient biological control agent of T. absoluta in some Mediterranean Basin countries when is used in combination with inoculative releases of the omnivorous predator Nesidiocoris tenuis (Reuter) (Hemiptera: Miridae) in commercial tomato greenhouses [3,23-25]. Moreover, experimental inundative releases of T. achaeae have showed promising control results of C. chalcites in banana crops of the Canary Islands when they are combined with pest monitoring and additional application of biological insecticides as the entomopathogenic bacteria Bacillus thuringiensis var. kurstaki [13]. Additionally, T. achaeae has also been successful released against Helicoverpa armigera Hübner (Lepidoptera: Noctuidae) and other bollworms species in cotton crops in India [26].

The successful selection and introduction of Trichogramma wasps in biological control programs is determined by some important factors such as the potential development of the parasitoid species or strain in the target host, beside some abiotic and physical factors [27-29]. Among these, temperature is the most important environmental factor that affects the distribution and abundance of Trichogramma [30], because it strongly determines biological parameters such as the development rate, survival, longevity, parasitism rate, viability, sex ratio, and emergence rate of the parasitoid wasps [31,32]. Understanding the thermal requirements of a selected Trichogramma species/strain is also essential for planning its mass rearing procedures in laboratory [30,33] and to determine its potential as a biological control agent for a given pest and region [31]. However, the temperature effects on the biological parameters and thermal requirements of Trichogramma depends on species/strains studied [34,35] and the host used [31,36].

Another essential factor determining the selection and efficiency of a Trichogramma species as biological control agent is the number of parasitized eggs in response to the parasitoid and host densities, i.e., its functional response [37], defined by Solomon [38] as the relationship between the number of preys consumed by a predator individual and the prey density. Functional response is a basic element to understand the host-parasitoid interactions and has a prominent influence on the stability of the system [39]. Following Holling [40], the general form of the functional response has 
been categorized into three types (Holling's type I, II, and III), according to the shape of the response curve below the upper limit. A type I response is characterized by a linear increase of killed host/prey to a plateau, a type II response by a curvilinear rise to a plateau that then levels off under the influence of handling time or satiation, and a type III response by a sigmoidal increase in hosts attacked [41,42]. In this sense, functional response is crucial for implementation of rapid population control required in inundative biological control [42]. Most Trichogramma species usually present a type I or type II functional response [42-46], but some studies have reported changes to type III because of the temperature [47,48] or the host typology [49].

Despite being a high economic importance species, the biology of T. achaeae is poorly studied [50-53], and no studies have been carried out in the past to determinate the variation on its life table parameters and functional response in relation to temperature, except its response to low temperatures for storage purposes [53-55] and improving its efficiency to control of T. absoluta [56]. Therefore, the aim of this work was to determine the life-cycle parameters and thermal requirements of $T$. achaeae, besides establishing its functional response in relation to temperature in Ephestia kuehniella Zeller (Lepidoptera: Pyralidae) eggs as an alternative host in order to optimize the mass production systems and inundative releases in the field of this parasitoid species for the biological control of $C$. chalcites and T. absoluta, among other lepidopteran pests.

\section{Materials and Methods}

\subsection{Insect Rearing}

A laboratory colony of T. achaeae was established from parasitized eggs of $C$. chalcites originally collected on banana crops in the locality of El Remo, La Palma, Canary Islands (Lat. 28 $33^{\prime} 21^{\prime \prime} \mathrm{N}$, Long. $17^{\circ} 53^{\prime} 17^{\prime \prime} \mathrm{W}$ ). Emerging wasps were successfully identified by examination of morphological characters and molecular characterization by sequencing of the ITS2 gene [18,21]. T. achaeae was reared for at least 15 generations before starting the trials, using fresh ultraviolet-sterilized eggs of E. kuehniella as factious host in a climatic chamber $\left(25 \pm 1{ }^{\circ} \mathrm{C}, 60-80 \% \mathrm{RH}\right.$ and $16: 8 \mathrm{~h} \mathrm{~L}$ :D photoperiod), according to the methodology proposed by Cabello et al. [23]. Factious host eggs were obtained from a culture of $E$. kuehniella massively reared following the methodology defined by Cerutti et al. [57]. A single layer of eggs of the factitious host were attached to a piece of paper, and the egg cards were offered to the adults of the parasitoid in glass vials $(9.5 \mathrm{~cm}$ large $\times 1.5 \mathrm{~cm}$ diameter), covered with cotton, and some droplets of honey-water solution (1:1) as a food source. Parasitized eggs were preserved into the glass vials until the emergence of the adult parasitoids. According to Cabello and Vargas [58], before any experiment was conducted, the parasitoids were reared for three generations at each temperature to eliminate any effects due to previous temperature treatment.

\subsection{Egg to Adult Developmental Time}

The egg to adult developmental time of $T$. achaeae was studied at $15,20,25,30$, and $35 \pm 1{ }^{\circ} \mathrm{C}$, with a $60-80 \% \mathrm{RH}$ and a $16: 8 \mathrm{~h} \mathrm{~L}: \mathrm{D}$ photoperiod in climatic chambers. From each temperature, newly emerged pairs (females and males) of $T$. achaeae were randomly chosen from the laboratory colony and exposed to fresh ultraviolet-sterilized eggs of E. kuehniella in small glass vials $(5 \times 1 \mathrm{~cm})$. After $24 \mathrm{~h}$, all parasitoids were removed, and 100 parasitized eggs $(<24 \mathrm{~h}$ old $)$ were individually isolated in glass vials with help of a wet fine brush (no. 0) and transferred to temperature-controlled chambers. Each isolated egg represented a replicate. Parasitized eggs were daily examined until the parasitoids completed their development and the sex of emerging wasps was recorded. Because larval development of $T$. achaeae occurs within the host egg, the immature stages (egg, larva, and pupa) were regarded as preadult stage (egg-pupa). 


\subsection{Adult Longevity and Fecundity}

The longevity and fecundity of T. achaeae adults were also evaluated at $15,20,25,30$, and $35 \pm 1{ }^{\circ} \mathrm{C}$, with a $60-80 \% \mathrm{RH}$ and 16:8 h L:D photoperiod. For each temperature, 20 male/female pairs less than one day old $(<24 \mathrm{~h})$ obtained in the development studies were separately isolated in small glass vials covered with cotton and a water-honey (1:1) drop for feed. Cardboards $(2 \times 2.5 \mathrm{~cm})$ with approximately 100 fresh irradiated E. kuehniella eggs were supplied daily until the natural death of the adults. Parasitized host eggs were removed daily and incubated at the above-mentioned conditions until the offspring emergence. Adult longevity, fecundity (number of eggs parasitized per female and day), as well as the emergence rate (number of individuals emerged), and the sex ratio of the progeny (\% female) were recorded.

\subsection{Functional Response}

The functional response of T. achaeae was determined at 15,25 and $35 \pm 1{ }^{\circ} \mathrm{C}$, with a $60-80 \%$ RH and 16:8 h L:D photoperiod following the methodology described by Cabello et al. [46]. In all cases, newly emerged (less than $24 \mathrm{~h}$ old) adult and mated females of T. achaeae without previous parasitation experience, and E. kuehniella eggs (less than $24 \mathrm{~h}$ old) were used. For each test (15, 25, and $35^{\circ} \mathrm{C}$ ), the experimental design was totally randomized with only one factor-host density at five levels (10, 30, 50, 70 and 90 E. kuehniella eggs), carrying out 10 repetitions for each level of treatment. One mated female of T. achaeae was used per replicate. Host eggs were attached using a wet fine brush to cardboards $(3 \times 1 \mathrm{~cm})$ in rows and columns separated $2 \mathrm{~mm}$. Adult females were individually isolated in small glass vials and offered an egg cardboard for $24 \mathrm{~h}$. Subsequently, the parasitoids were eliminated, and the egg cardboards were evolved up to offspring emergence. The registered data were parasitized eggs, emerged host larvae, and collapsed eggs.

\subsection{Statistical Analysis}

Development time, fecundity, and adult longevity data under different temperature regimes were transformed to $\log 10(x+1)$, while emergence rate and sex ratio data were transformed to arcsine $(\sqrt{ }(x / 100))$. All transformed data were analyzed by ANOVA test applying the GLM procedure and the average values were compared by Tukey's test $(p=0.05)$ by means of the statistical software IBM $^{\circledR}$ SPSS ${ }^{\circledR}$ Statistics Version 22 [59]. The thermal constant and lower threshold temperature for development was calculated according to the linear thermodynamic model described by Ikemoto and Takai [60],

$$
D T=k+t D
$$

where DT is the product of development time in days $(D)$ and temperature $(T)$ in degrees Celsius $\left({ }^{\circ} \mathrm{C}\right)$. The intercept, $k$, is the thermal constant in degree days $\left({ }^{\circ} \mathrm{d}\right)$, and the slope, $t$, the lower development threshold in ${ }^{\circ} \mathrm{C}$. The parameters $t$ and $k$ were determined by linear regression.

The raw data on T. achaeae life history reared on E. kuehniella eggs at above temperatures were analyzed in accordance with the age-stage, two-sex life table theory [61,62], by means of the software TWOSEX-MSChart ${ }^{\circledR}$ [63], and the results were plotted with SigmaPlot ${ }^{\circledR}$ Version 14.0 (Systat Software, Inc., San Jose, CA, USA). Life table parameters were calculated including age-stage specific survival rate $\left(s_{x j}\right)$ (where $x$ is age in days and $j$ is stage), age-stage specific fecundity $\left(f_{x j}\right)$, age-specific survival rates $\left(l_{x}\right)$, age-specific fecundity $\left(m_{x}\right)$, life expectancy $\left(e_{x j}\right)$, reproductive value $\left(v_{x j}\right)$ and the intrinsic rate of increase $(r)$, finite rate of increase $(\lambda)$, gross reproductive rate $(G R R)$, net reproductive rate $\left(R_{0}\right)$ and mean generation time $(T)$, according to earlier theories $[61,64]$. Bootstrap technique with 100,000 resamples [65] was utilized to calculate the means values, variances, and standard errors of the population parameters [66]. A paired bootstrap test was used for statistical analysis.

For the experiment concerning to the functional response of T. achaeae after adjustments data were submitted to two classes of statistical analysis. First, the density factor significance was determined by GLM analysis and the average values were compared by Tukey's test $(p=0.05)$ by means of the statistical 
software IBM ${ }^{\circledR}$ SPSS ${ }^{\circledR}$ Statistics Version 22 [59]. Second, the three equations of functional response (types I, II, and III) were then adjusted for T. achaeae, according to the following expressions $[46,67,68]$ :

$$
\begin{gathered}
\text { Type I : } N_{a}=N_{t}\left[1-\exp \left(-a^{\prime} \cdot T \cdot P_{t}\right)\right] \\
\text { Type II : } N_{a}=N_{t} \cdot\left[1-\exp \left(-\frac{a^{\prime} \cdot T \cdot P_{t}}{1+a^{\prime} \cdot T_{h} \cdot N_{t}}\right)\right] \\
\text { Type III : } N_{a}=N_{t} \cdot\left[1-\exp \left(-\frac{\alpha \cdot T \cdot N_{t} \cdot P_{t}}{1+\alpha \cdot T_{h} \cdot N_{t}+\alpha \cdot T_{h} \cdot N_{t}^{2}}\right)\right]
\end{gathered}
$$

where $N_{a}$ is the number of parasitized hosts; $N_{t}$ is the density of the host or prey; $a^{\prime}$ is the instantaneous search rate (equivalent to Nicholson-Bailey's "area of discovery": $a=a^{\prime} T$, days ${ }^{-1}$ ); $T$ is the total available search time (days); $P_{t}$ is the number of parasitoids; $T_{h}$ is the host-manipulation time; and $\alpha$ is parasitoid mortality potential.

The cited adjustments were performed by means of the software Tablecurve 2D, version 5.0 [69]. The corrected Akaike information criterion (AICc) was applied to select the best adjustment model, as it offers better statistical precision for comparisons between models than the regression coefficient $\left(r^{2}\right)$ [70]. However, the latter was calculated to determine the goodness of each performed adjustment.

\section{Results}

\subsection{Egg to Adult Developmental Time}

T. achaeae was able to develop and emerge between $15^{\circ} \mathrm{C}$ and $30^{\circ} \mathrm{C}$ on E. kuehniella eggs (Table 1). Statistical analysis manifested a significant influence of temperature on the egg-adult developmental time $(F=12,262.13, \mathrm{df}=3, p<0.001)$. The developmental time was higher at lower temperatures, which ranged from $31.08 \mathrm{~d}$ at $15{ }^{\circ} \mathrm{C}$ to 7.55 days at $30{ }^{\circ} \mathrm{C}$. In cultures maintained at $35^{\circ} \mathrm{C}$ only emerged some adults of T. achaeae, which showed poor development of the wings and longevity less than $24 \mathrm{~h}$, and none of the E. kuehniella offered eggs were parasitized, indicating that $35^{\circ} \mathrm{C}$ exceeded the upper threshold. The egg-adult developmental time was not significantly different between males and females at the tested temperatures.

Table 1. Development time, adult longevity, adult preoviposition period (APOP), total preoviposition period (TPOP), oviposition period, fecundity, percentage of adult emergence, and sex ratio (mean $\pm \mathrm{SE}$ ) of Trichogramma achaeae reared on Ephestia kuehniella eggs at different temperatures under laboratory conditions (60-80\% RH and 16:8 h L:D).

\begin{tabular}{ccccc}
\hline Parameters & \multicolumn{4}{c}{ Temperature $\left({ }^{\circ} \mathbf{C}\right)$} \\
\cline { 2 - 5 } & $\mathbf{1 5}$ & $\mathbf{2 0}$ & $\mathbf{2 5}$ & $\mathbf{3 0}$ \\
\hline Total development time & $31.08 \pm 0.14 \mathrm{a}$ & $14.52 \pm 0.08 \mathrm{~b}$ & $8.83 \pm 0.05 \mathrm{c}$ & $7.55 \pm 0.07 \mathrm{~d}$ \\
(days) & $12.75 \pm 1.22 \mathrm{a}$ & $9.55 \pm 0.67 \mathrm{~b}$ & $7.10 \pm 0.35 \mathrm{bc}$ & $5.55 \pm 0.40 \mathrm{c}$ \\
Female longevity (days) & $9.12 \pm 1.04 \mathrm{a}$ & $5.65 \pm 0.42 \mathrm{~b}$ & $3.95 \pm 0.38 \mathrm{bc}$ & $3.40 \pm 0.47 \mathrm{c}$ \\
Male longevity (days) & $2.15 \pm 0.49 \mathrm{a}$ & $0.00 \pm 0.00 \mathrm{~b}$ & $0.00 \pm 0.00 \mathrm{~b}$ & $0.00 \pm 0.00 \mathrm{~b}$ \\
APOP (days) & $33.15 \pm 0.49 \mathrm{a}$ & $14.49 \pm 0.11 \mathrm{~b}$ & $8.82 \pm 0.06 \mathrm{c}$ & $7.66 \pm 0.10 \mathrm{~d}$ \\
TPOP (days) & $10.95 \pm 1.13 \mathrm{a}$ & $8.60 \pm 0.69 \mathrm{ab}$ & $7.50 \pm 0.39 \mathrm{bc}$ & $5.70 \pm 0.37 \mathrm{c}$ \\
Oviposition period (days) & $28.45 \pm 2.83 \mathrm{~b}$ & $64.05 \pm 4.57 \mathrm{a}$ & $55.75 \pm 3.60 \mathrm{a}$ & $54.30 \pm 4.57 \mathrm{a}$ \\
Fecundity (eggs/female) & $77.52 \pm 2.21 \mathrm{c}$ & $86.31 \pm 1.88 \mathrm{~b}$ & $89.88 \pm 1.65 \mathrm{~b}$ & $95.43 \pm 0.64 \mathrm{a}$ \\
Emergence (\%) & $68.10 \pm 1.90 \mathrm{a}$ & $63.15 \pm 1.66 \mathrm{ab}$ & $59.64 \pm 1.69 \mathrm{~b}$ & $48.41 \pm 0.91 \mathrm{c}$ \\
Sex offspring (\% female) & $31.90 \pm 1.90 \mathrm{c}$ & $36.85 \pm 1.66 \mathrm{bc}$ & $40.36 \pm 1.69 \mathrm{~b}$ & $51.59 \pm 0.91 \mathrm{a}$ \\
Sex offspring (\% male) & $2.13: 1$ & $1.71: 1$ & $1.48: 1$ & $0.94: 1$ \\
Sex ratio (F:M) & &
\end{tabular}

Means in each row followed by the same letter are not different using Tukey test $(p<0.05)$. 
Developmental rate of T. achaeae fit the linear model suggested by Ikemoto and Takai [60]. The lower threshold temperature $(t)$ was estimated in $10.51 \pm 0.51^{\circ} \mathrm{C}$, while the thermal constant $(k)$ was $138.27 \pm 9.27^{\circ} \mathrm{d}\left(r^{2}=0.995, F=419.02, \mathrm{df}=1, p<0.001\right)$.

\subsection{Adult Longevity and Fecundity}

The effects of different temperatures on the adult longevity, fecundity, preoviposition and oviposition periods, percentage of adult emergence, and sex of offspring of T. achaeae for each temperature tested are given in the Table 1 . Significant effects of temperature were recorded on longevity of females $(F=17.82, \mathrm{df}=3, p<0.001)$ and males $(F=17.50, \mathrm{df}=3, p<0.001)$. In both cases, the adult longevity increased with the decrease of temperature, the maximum of $15^{\circ} \mathrm{C}$ with $12.75 \pm$ $1.22 \mathrm{~d}$ and $9.12 \pm 1.04$ days for females and males, respectively. There were significant differences in the longevity of $T$. achaeae females as compared to their conspecific males at the same temperature $(t=5.456, \mathrm{df}=155, p<0.001)$. Adult female longevity was longer than male longevity at every tested temperature (Table 1 ).

The number of parasitized eggs per female (fecundity) was influenced by temperature and revealed significant differences between the tested temperatures $(F=15.15, \mathrm{df}=3, p<0.001)$. The mean number of parasitized eggs were highest at $20^{\circ} \mathrm{C}(64.05 \pm 4.57 \mathrm{eggs} / \mathrm{female})$ and lowest at $15^{\circ} \mathrm{C}(28.45 \pm 2.83 \mathrm{eggs} /$ female $)$ with intermediate values in the remaining temperatures. The adult preoviposition period (APOP) and total preoviposition period (TPOP) of T. achaeae were significantly different for the tested temperatures $(F=18.98$, $\mathrm{df}=3, p<0.001$ for APOP and $F=2232.46, \mathrm{df}=3, p<$ 0.001 for TPOP). No APOP was observed for the female parasitoids emerged at different temperatures tested, except at $15{ }^{\circ} \mathrm{C}(2.15 \pm 0.49 \mathrm{~d})$. The females developed at $30{ }^{\circ} \mathrm{C}$ showed the shortest TPOP $(7.66 \pm 0.10 \mathrm{~d})$, but the highest was detected at $15^{\circ} \mathrm{C}(33.15 \pm 0.49 \mathrm{~d})$. Temperature also significantly influenced the mean oviposition period of T. achaeae $(F=9.48, \mathrm{df}=3, p<0.001)$, with the maximum at $15^{\circ} \mathrm{C}(10.95 \pm 1.13 \mathrm{~d})$ and minimum at $30{ }^{\circ} \mathrm{C}(5.70 \pm 0.37 \mathrm{~d})$.

The percentage of adult emergence (fertility) was also significantly affected by temperature $(F=19.94, \mathrm{df}=3, p<0.001)$. The highest adult emergence rate occurred at $30^{\circ} \mathrm{C}(95.43 \pm 0.64 \%)$, while the lowest was still at $15{ }^{\circ} \mathrm{C}(77.52 \pm 2.21 \%)$. A female-biased sex ratio was recorded for T. achaeae under the temperature regimes studied. There was a significant difference in the sex ratios $(F=26.81$, $\mathrm{df}=3, p<0.001)$ at tested temperatures. The values ranged from $48.41 \pm 0.91 \%$ to $68.10 \pm 1.90 \%$ females at $30^{\circ} \mathrm{C}$ and $15^{\circ} \mathrm{C}$, respectively.

\subsection{Age-Stage, Two-Sex Life Table of T. achaeae}

According to the age-stage, two-sex life table theory, population parameters of T. achaeae were projected using the data of the entire cohort. Based on our results, population parameters exhibited significant differences over the rearing temperature (Table 2).

Table 2. Population parameters (mean \pm SE) of Trichogramma achaeae reared on Ephestia kuehniella eggs at different temperatures under laboratory conditions (60-80\% RH and 16:8 h L:D).

\begin{tabular}{ccccc}
\hline \multirow{2}{*}{ Parameters } & \multicolumn{4}{c}{ Temperature $\left({ }^{\circ} \mathbf{C}\right)$} \\
\cline { 2 - 5 } & $\mathbf{1 5}$ & $\mathbf{2 0}$ & $\mathbf{2 5}$ & $\mathbf{3 0}$ \\
\hline$R_{0}$ (offspring) & $14.075 \pm 2.591 \mathrm{c}$ & $32.000 \pm 5.519 \mathrm{a}$ & $27.875 \pm 4.756 \mathrm{~b}$ & $27.150 \pm 4.843 \mathrm{~b}$ \\
$r\left(\right.$ day $\left.^{-1}\right)$ & $0.072 \pm 0.005 \mathrm{c}$ & $0.195 \pm 0.010 \mathrm{~b}$ & $0.284 \pm 0.015 \mathrm{a}$ & $0.319 \pm 0.017 \mathrm{a}$ \\
$\lambda\left(\right.$ day $\left.^{-1}\right)$ & $1.075 \pm 0.006 \mathrm{c}$ & $1.215 \pm 0.012 \mathrm{~b}$ & $1.328 \pm 0.020 \mathrm{a}$ & $1.375 \pm 0.024 \mathrm{a}$ \\
$T$ (day) & $36.707 \pm 0.397 \mathrm{a}$ & $17.761 \pm 0.132 \mathrm{~b}$ & $11.728 \pm 0.156 \mathrm{c}$ & $10.357 \pm 0.100 \mathrm{~d}$ \\
$G R R$ (offspring) & $23.070 \pm 3.908 \mathrm{c}$ & $46.210 \pm 6.713 \mathrm{a}$ & $42.280 \pm 5.817 \mathrm{~b}$ & $41.520 \pm 5.861 \mathrm{~b}$ \\
\hline
\end{tabular}

$R_{0}$ : net reproduction rate. $r$ : intrinsic rate of increase. $\lambda$ : finite rate of increase. T: mean generation time. GRR: gross reproductive rate. Means in each row followed by the same letter are not different using paired bootstrap procedure $(p<0.05)$ 
The greatest value of the net reproductive rate $\left(R_{0}\right)$ was observed at $20{ }^{\circ} \mathrm{C}(32.00 \pm 5.52$ eggs per individual $)$ and the lowest at $15^{\circ} \mathrm{C}(14.08 \pm 2.59$ eggs per individual). The intrinsic rate of increase $(r)$ of the parasitoid also increased as temperature increased, recording the lowest value at $15^{\circ} \mathrm{C}(0.072 \pm$ $\left.0.005 \mathrm{~d}^{-1}\right)$ and the highest at $30^{\circ} \mathrm{C}\left(0.319 \pm 0.017 \mathrm{~d}^{-1}\right)$. The highest value for the finite rate of increase $(\lambda)$ occurred at $30^{\circ} \mathrm{C}\left(1.38 \pm 0.02 \mathrm{~d}^{-1}\right)$ because of the shorter duration of one generation. Finally, the mean generation time $(T)$ decreased with increased temperature and ranged from $10.36 \pm 0.10 \mathrm{~d}$ at $30^{\circ} \mathrm{C}$ to $36.71 \pm 0.39 \mathrm{~d}$ at $15^{\circ} \mathrm{C}$.

The age-stage-specific survival rate $\left(s_{x j}\right)$ indicates the probability that an individual (as a newly laid egg) of T. achaeae will survive to age $x$ and develop to stage $j$, depending on temperature is shown in Figure 1. These curves also show the survivorship and stage differentiation as well as the variable developmental rates. The survival rate of T. achaeae was highest at $15^{\circ} \mathrm{C}$ and lowest at $30{ }^{\circ} \mathrm{C}$.
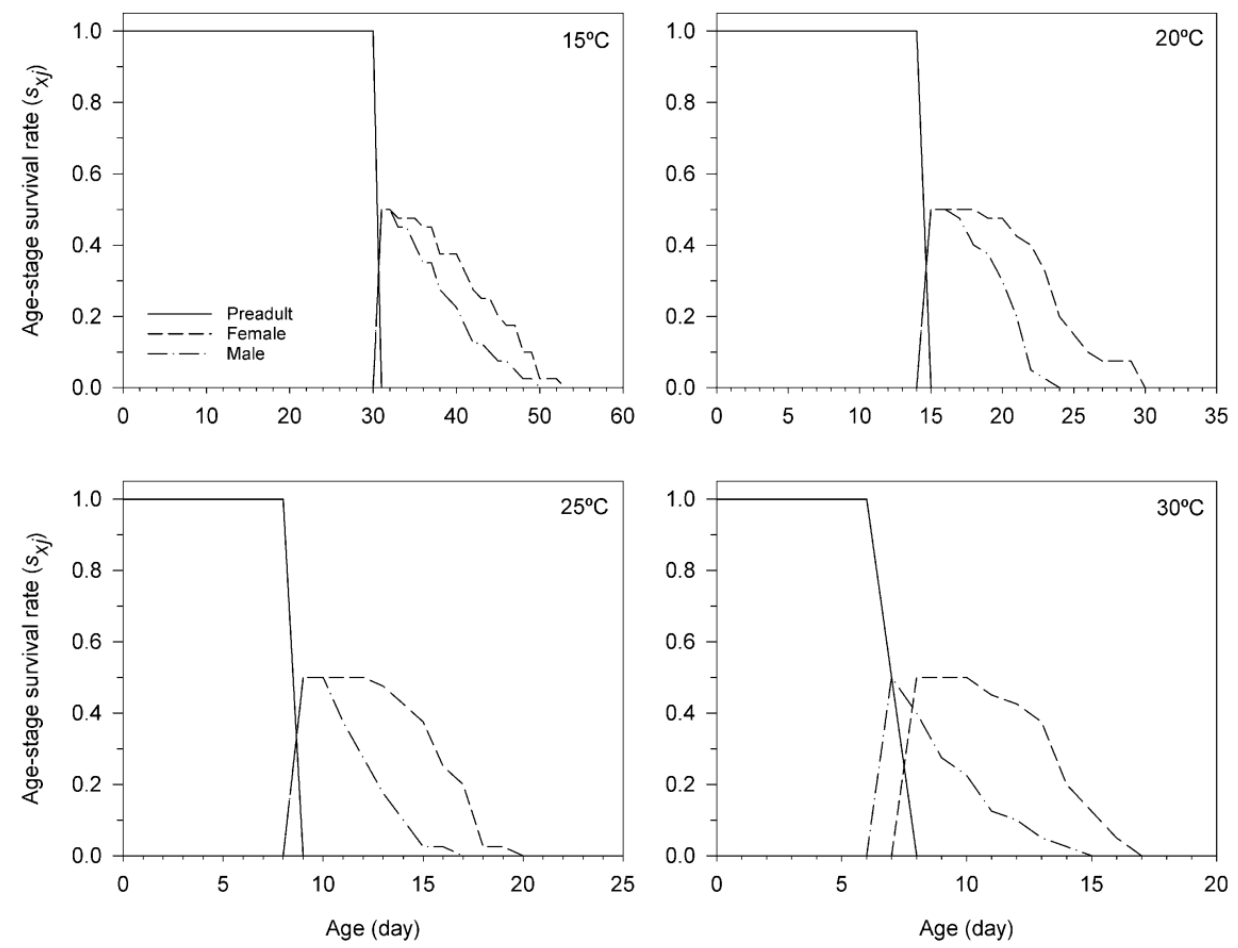

Figure 1. Age-stage survival rate $\left(s_{x j}\right)$ of Trichogramma achaeae reared at 15, 20, 25, and $30^{\circ} \mathrm{C}$ on Ephestia kuehniella eggs, using the age-stage, two-sex life table.

The age-specific survivorship $\left(l_{x}\right)$, age-stage specific fecundity $\left(f_{x}\right)$, and age-specific fecundity $\left(m_{x}\right)$ of T. achaeae reared on E. kuehniella eggs at different temperatures are illustrated in Figure 2. They indicate that T. achaeae can successfully survive and reproduce on E. kuehniella eggs between $15^{\circ} \mathrm{C}$ and $30^{\circ} \mathrm{C}$. The curves of age-specific survival rate $\left(l_{x}\right)$ show the probability that a newly laid egg will survive to age $x$. The survival rate of T. achaeae individuals at various temperatures was different. While the longest survival rate $(53 \mathrm{~d})$ occurred at $15^{\circ} \mathrm{C}$, its shortest value $(17 \mathrm{~d})$ was observed at $30^{\circ} \mathrm{C}$. The age-stage-specific fecundity $\left(f_{x j}\right)$ is the daily mean number of offspring produced by individual T. achaeae of age $x$ and stage $j$ per day. According to our results, the highest value of age-stage specific fecundity $\left(f_{x j}\right)$ of $T$. achaeae at $15,20,25$ and $30^{\circ} \mathrm{C}$ was $4.05,22.40,15.10$ and 15.95 eggs per female and day, respectively, happening at the age of $32,15,9$ and $8 \mathrm{~d}$, respectively. The age-specific fecundity $\left(m_{x}\right)$ is the mean number of eggs produced per individual at age $x$. The age-specific maternity $\left(l_{x} m_{x}\right)$ values changed depending on $l_{x}$ and $m_{x}$, and the highest peak values of $l_{x} m_{x}$ occurred at the age of 32, 15, 9 and $8 \mathrm{~d}$ at $15,20,25$ and $30^{\circ} \mathrm{C}$, respectively. In accordance with the curves, the greatest fecundity happened in the two first days after female emergence. 

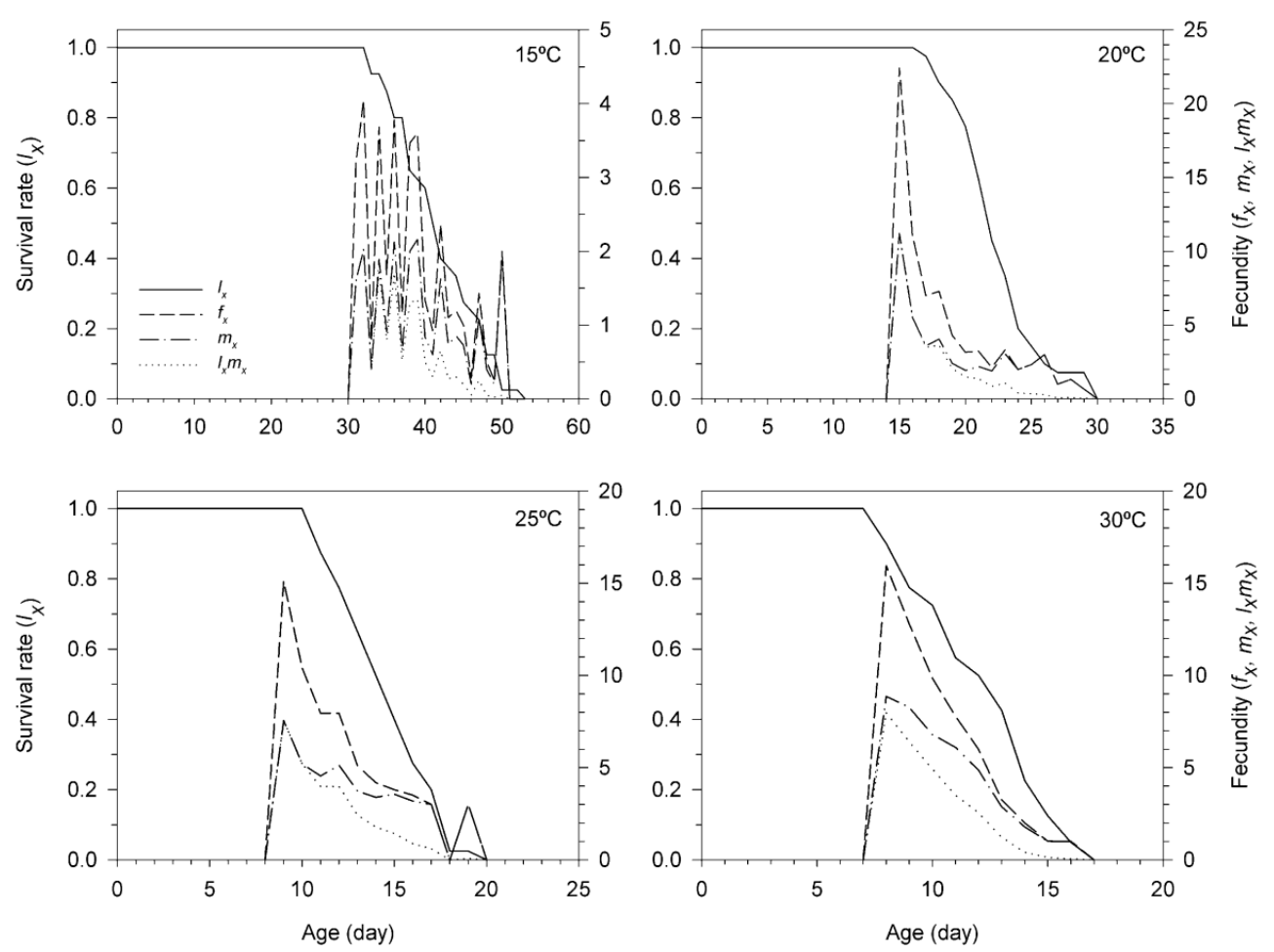

Figure 2. Age-specific survival rate $\left(l_{x}\right)$, age-stage specific fecundity $\left(f_{x j}\right)$, age-specific fecundity $\left(m_{x}\right)$ and age-specific maternity $\left(l_{x} m_{x}\right)$ of Trichogramma achaeae reared at $15,20,25$ and $30{ }^{\circ} \mathrm{C}$ on Ephestia kuehniella eggs, using the age-stage, two-sex life table.

Figure 3 shows the age-stage-specific life expectancy $\left(e_{x j}\right)$ of $T$. achaeae, which estimates the time that an individual of age $x$ and stage $j$ is expected to live. According to our results, the life expectancy of newly T. achaeae females was $12.75,9.55,7.55$ and $6.25 \mathrm{~d}$ at $15,20,25$ and $30^{\circ} \mathrm{C}$, respectively.
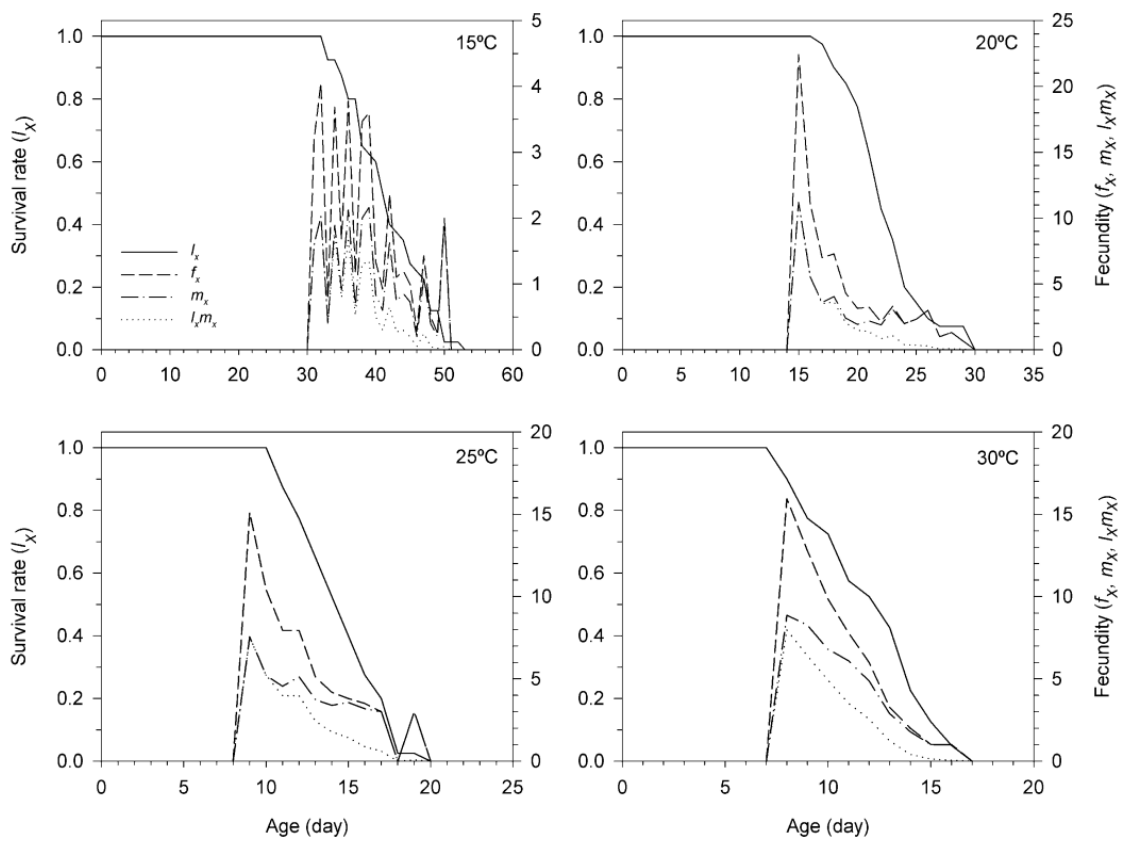

Figure 3. Age-stage-specific life expectancy $\left(e_{x j}\right)$ of Trichogramma achaeae reared at $15,20,25$ and $30{ }^{\circ} \mathrm{C}$ on Ephestia kuehniella eggs, using the age-stage, two-sex life table. 
The curves of reproductive value $\left(v_{x j}\right)$ of T. achaeae are given in Figure 4 . This parameter predicts the contribution of an individual of age $x$ and stage $j$ to the future population. Therefore, the reproductive value for the egg-pupa stage symbolizes the contributions of egg and pupal stages to the future population. The $v_{x j}$ for the egg-pupa stage of $T$. achaeae differed at temperatures tested, and adult female $v_{x j}$ peak was significantly highest at $20^{\circ} \mathrm{C}$ but lowest at $15{ }^{\circ} \mathrm{C}$, and it occurred earliest at $30^{\circ} \mathrm{C}$ but latest at $15^{\circ} \mathrm{C}$. The highest adult female $v_{x j}$ peaks significantly raised drastically to 20.05 at $31 \mathrm{~d}$ at $15{ }^{\circ} \mathrm{C}$ to 45.38 at $15 \mathrm{~d}$ at $20^{\circ} \mathrm{C}$ to 34.14 at nine $\mathrm{d}$ at $25^{\circ} \mathrm{C}$ and to 35.23 at eight days at $30^{\circ} \mathrm{C}$.
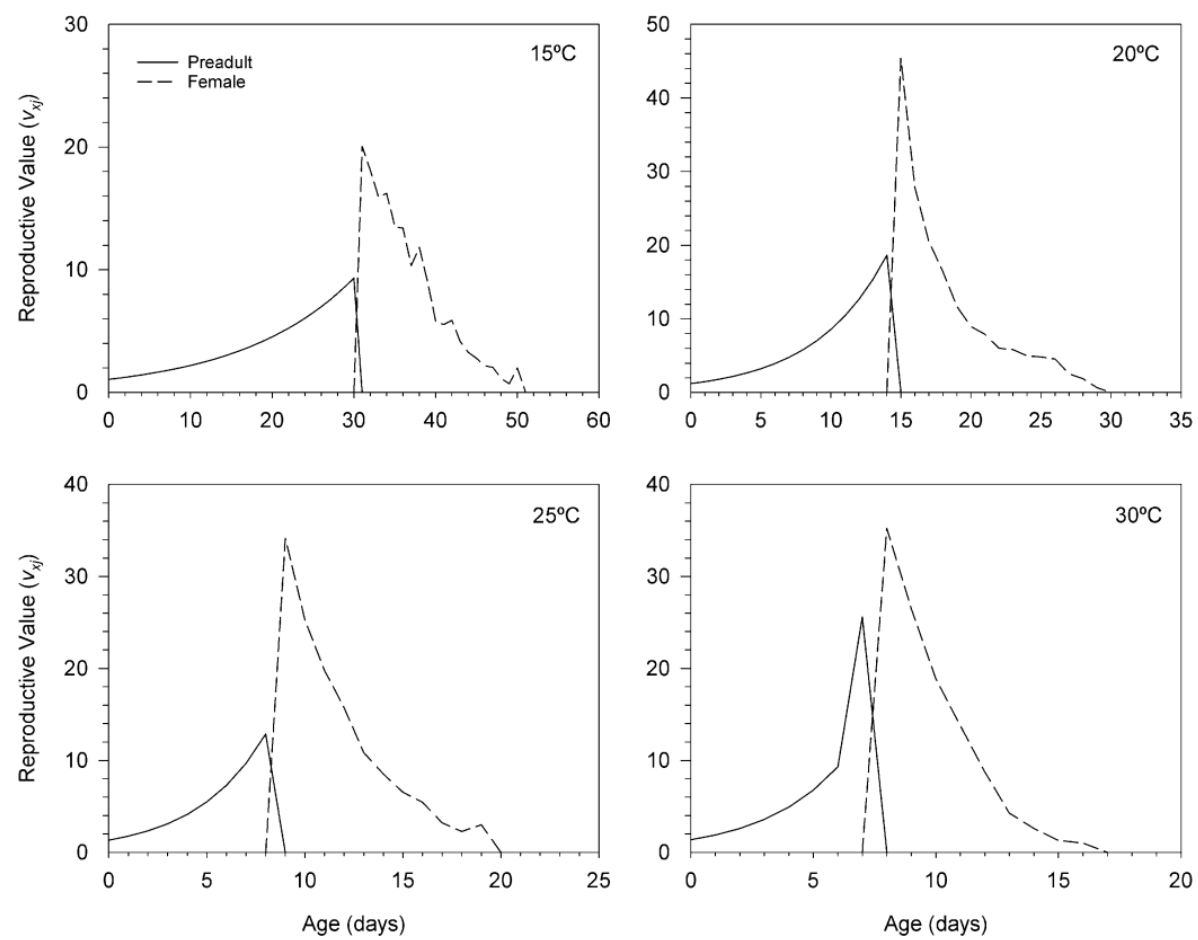

Figure 4. Age-stage reproductive value $\left(v_{x j}\right)$ of Trichogramma achaeae reared at $15,20,25$ and $30{ }^{\circ} \mathrm{C}$ on Ephestia kuehniella eggs, using the age-stage, two-sex life table.

\subsection{Functional Response of T. achaeae}

Table 3 illustrates the mean number of parasitized eggs in the functional response test of T. achaeae at $15^{\circ} \mathrm{C}$ and $25^{\circ} \mathrm{C}$, using E. kuehniella as host under laboratory conditions. The analysis of variance revealed a greatly significant effect of the host density on parasitism for each examined temperature $\left(F=17.04, \mathrm{df}=4, p<0.001\right.$ at $15^{\circ} \mathrm{C}$ and $F=19.65, \mathrm{df}=4, p<0.001$ at $\left.25^{\circ} \mathrm{C}\right)$. The greatest temperature $\left(25^{\circ} \mathrm{C}\right)$ can be observed to lead to higher quantities of parasitized eggs (average 16.78 eggs) than the lowest temperature $\left(15^{\circ} \mathrm{C}\right.$, average 12.70 eggs $)$.

Table 3. Number of Ephestia kuehniella eggs parasitized by Trichogramma achaeae females according to host density and temperature under laboratory conditions (60-80\% RH and 16:8 h L:D).

\begin{tabular}{cccc}
\hline \multirow{2}{*}{ Egg Density } & \multicolumn{2}{c}{ Temperature $\left({ }^{\circ} \mathbf{C}\right)$} & \multirow{2}{*}{ Average } \\
\cline { 2 - 3 } & $\mathbf{1 5}$ & $\mathbf{2 5}$ & \\
\hline 10 & $7.50 \pm 0.73 \mathrm{c}$ & $8.90 \pm 0.28 \mathrm{c}$ & $8.20 \pm 0.41$ \\
30 & $16.00 \pm 1.06 \mathrm{a}$ & $16.20 \pm 1.10 \mathrm{~b}$ & $16.10 \pm 0.75$ \\
50 & $15.20 \pm 0.63 \mathrm{ab}$ & $17.70 \pm 1.16 \mathrm{ab}$ & $16.45 \pm 0.70$ \\
70 & $12.40 \pm 0.96 \mathrm{~b}$ & $19.60 \pm 1.53 \mathrm{ab}$ & $16.00 \pm 1.21$ \\
90 & $12.40 \pm 0.96 \mathrm{~b}$ & $21.50 \pm 0.99 \mathrm{a}$ & $16.95 \pm 1.18$ \\
Average & $12.70 \pm 0.55$ & $16.78 \pm 0.77$ & \\
\hline
\end{tabular}

Means followed by the same letter in the same column are not significantly different at $p<0.05$ (Tukey test). 
A type I functional response corresponded to the values of the number parasitized eggs (according to density) at $15^{\circ} \mathrm{C}$ and a type II functional response at $25^{\circ} \mathrm{C}$ (Figure 5), whose adjustments showed lower values in the corrected Akaike indices (AICc) (Table 4). The instantaneous search rate $\left(a^{\prime}\right)$ was maximum at $25{ }^{\circ} \mathrm{C}\left(11.834 \mathrm{~h}^{-1}\right)$ and minimum at $15{ }^{\circ} \mathrm{C}\left(0.8097 \mathrm{~h}^{-1}\right)$. Host-manipulation time was $0.0414 \mathrm{~h}$ at $25^{\circ} \mathrm{C}$ and very low at $15^{\circ} \mathrm{C}$. At $35^{\circ} \mathrm{C}$, females of T. achaeae were able to survive for $24 \mathrm{~h}$; however, the percentage of parasitism found was very low, so that these values were not allowed to adjust the functional response. Also, the further development of the offspring of females did not occur to any of the densities studied. In this case, the effect was caused by the high mortality of E. kuehniella eggs at $35^{\circ} \mathrm{C}$, which collapsed and dried even when parasitized.
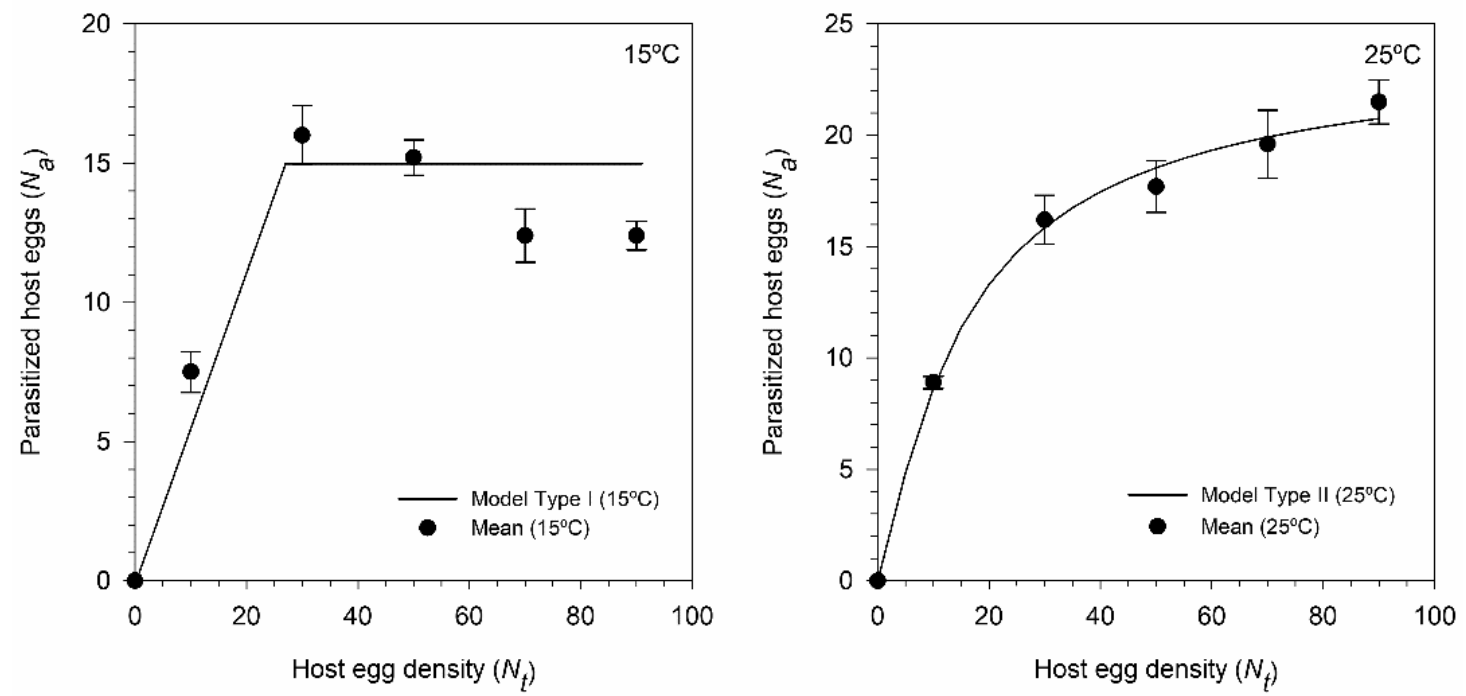

Figure 5. Functional response of Trichogramma achaeae female parasitizing Ephestia kuehniella eggs at two different temperature levels and under laboratory conditions (60-80\% R.H. and 16:8 h L:D). (Vertical lines represent standard errors of models, $p=0.05$ ).

Table 4. Parameters and statistical significance for functional response equations for number of Ephestia kuehniella eggs parasitized by Trichogramma achaeae females, at two temperatures (15 and $25 \pm 2{ }^{\circ} \mathrm{C}$ ) under laboratory conditions (60-80\% RH and 16:8 h L:D).

\begin{tabular}{cccccccc}
\hline \multirow{2}{*}{ Temperature $\left({ }^{\circ} \mathbf{C}\right)$} & \multirow{2}{*}{ Type } & \multicolumn{4}{c}{ Parameters ${ }^{\mathbf{1}}$} & \multicolumn{3}{c}{ Statistical Parameters } \\
\cline { 3 - 7 } & & $\boldsymbol{T}_{\boldsymbol{h}}$ & $\boldsymbol{a}^{\prime}$ & $\boldsymbol{\alpha}$ & AICc & df & $\boldsymbol{r}^{\mathbf{2}}$ \\
\hline \multirow{2}{*}{15} & I & - & 0.8097 & - & 4.0076 & 3 & 0.9342 \\
& II & 0.0706 & 9.9374 & - & 11.259 & 5 & 0.7695 \\
& III & 0.0629 & - & 2.3843 & 11.440 & 5 & 0.7612 \\
\multirow{2}{*}{25} & I & - & 0.8557 & - & 8.8033 & 3 & 0.8325 \\
& II & 0.0414 & 11.834 & - & -2.5839 & 5 & 0.9923 \\
& III & 0.0422 & - & 15.548 & -2.3435 & 5 & 0.9901 \\
\hline
\end{tabular}

\footnotetext{
${ }^{1}$ Parameters: $a^{\prime}$, instantaneous search rate $\left(\mathrm{h}^{-1}\right) ; \alpha$, parasitoid mortality potential; $T_{h}$, host-manipulation time $(\mathrm{h})$.
}

\section{Discussion}

According to Samara et al. [71], temperature is considered the most significant abiotic factor directly influencing development rate, cumulative fertility, adult longevity, sex ratio and emergence rate of Trichogramma. In the present study, we evaluated the influence of five constant temperatures $\left(15,20,25,30\right.$ and $\left.35^{\circ} \mathrm{C}\right)$ on the biological characteristics and two-sex life table parameters of T. achaeae when it is reared in E. kuehniella eggs under laboratory conditions. Results in the current study clearly showed that temperature significantly affected the preadult development time, decreasing when temperature was increased from $15^{\circ} \mathrm{C}$ to $30^{\circ} \mathrm{C}$. According to Bueno et al. [72], this shortening of development time is caused by an increase in the metabolic activity of the immature stages at 
higher temperatures. The tendency of variation between temperatures was similar for both sexes, and differences in developmental time were not observed between T. achaeae females and males at all tested temperatures. Similar results have been published by other authors in biological studies of different Trichogramma species [30,35,58,72,73]. In our study, the egg to adult development of T. achaeae at $25^{\circ} \mathrm{C}$ was completed in $8.83 \mathrm{~d}$ in E. kuehniella eggs, lower than the $10.4 \mathrm{~d}$ and $10.8 \mathrm{~d}$ recorded by Ghosh et al. [51] and Manohar et al. [52] in Corcyra cephalonica Stainton (Lepidoptera: Pyralidae) and T. absoluta eggs, respectively. These differences might be associated with the effect of the size and nutritional quality of the host egg on the preimaginal development and adult fitness of Trichogramma spp., as suggested by Kishani Farahani et al. [74]. Our studies indicated that T. achaeae developed successfully from egg to adult in the temperature range of $15^{\circ} \mathrm{C}$ to $30{ }^{\circ} \mathrm{C}$. On the other hand, the parasitized host eggs turned black at $35^{\circ} \mathrm{C}$, but many of them collapsed, dried, and no viable progeny emerged, showing a negative effect of high temperature, thus exceeding the upper threshold. The high temperature preventing the adult emergence observed in our study agrees with previous works [34,58]. However, Ghosh et al. [51] found that T. achaeae was successfully able to develop and emerge at $36^{\circ} \mathrm{C}$ in C. cephalonica eggs.

Knowledge of thermal requirements allows us to expect the number of generations of Trichogramma spp. and the best time for the release of the parasitoids in the field [31]. In the present work, temperature thresholds and thermal requirements of T. achaeae were calculated according to linear model suggested by Ikemoto and Takai [60]. Our results showed that the developmental threshold temperature $(t)$ and the effective accumulated temperature $(k)$ values for egg to adult were $10.51{ }^{\circ} \mathrm{C}$ and $138.27^{\circ} \mathrm{d}$, respectively. These values were close to those previously reported for T. achaeae [51] and for other subtropical Trichogramma species [35], suggesting a tolerance of this species to low temperatures. In this line, several authors indicated that pupae of T. achaeae can be successfully placed at $10^{\circ} \mathrm{C}$ for short term storage up to 30 days, resulting in an adult emergence percentage of $60 \%$ at this temperature $[53,55]$. The time taken for T. achaeae to complete its development at $15{ }^{\circ} \mathrm{C}(31.08 \mathrm{~d})$ shows that the development rate in preadult stages within E. kuehniella eggs is prolonged at lower temperatures. In this sense, earlier studies suggest that immature stages inside the host are the dominant overwintering stage of Trichogramma [35], that corroborates the theory that T. achaeae does not enter diapause, its development being slower through the winter months [3,56]. On the other hand, the absence of diapause in T. achaeae can cause difficulty in storage and handling, which, together with its biparental reproduction, makes the use of this parasitoid more difficult and expensive as biological control agent [24,56].

The current study showed that temperature significantly affected adult longevity, fecundity, parasite emergence, and sex ratio of T. achaeae. As observed in other Trichogramma species $[27,30,75]$, the mean adult longevity of $T$. achaeae females and males decreased as temperature increased, recording the highest longevity at $15^{\circ} \mathrm{C}$, for both females and males. According to Foerster et al. [75], increase in adult longevity may be due to a reduction of parasitoid activity and metabolic rate at low temperatures. The results also showed that $T$. achaeae can reproduce through the studied temperature range of $15-30{ }^{\circ} \mathrm{C}$ on E. kuehniella eggs. The highest number of parasitized eggs or fecundity was found at $20^{\circ} \mathrm{C}$ (64.05 eggs per female) and then decreased as temperature increased. These results are according with those found for other species as T. cordubensis Vargas and Cabello [58] and T. aurosum Sugonjaev and Sorokina [71], where the parasitized host eggs number increased with increasing temperature to a maximum at $20-25^{\circ} \mathrm{C}$ and declined at $30^{\circ} \mathrm{C}$. The deleterious effect of high temperature on the fecundity may be caused by the reduction in female longevity [58]. On the other hand, consulted references have shown an important variation in the number of eggs parasitized by T. achaeae according to the rearing host. We found that females of T. achaeae parasitized 55.75 eggs of E. kuehniella at $25^{\circ} \mathrm{C}$, in line with the 58.4 eggs of C. cephalonica reported by Ghosh et al. [51], but higher than the 35.37 eggs of E. kuehniella, and the 22.13 eggs of T. absoluta found by Melo [76] and Manohar et al. [52], respectively. Likewise, it is known that the adult longevity and reproductive skills of Trichogramma spp. may change in accordance with the temperature [73] and host nutritional quality during the development [74] and food in the adult stage [77]. The fertility was maximum at the first $24 \mathrm{~h}$ after emergence of $T$. 
achaeae females, and no preoviposition period was detected at all tested temperatures, except at $15^{\circ} \mathrm{C}$. After the first day, the oviposition peak consistently declined until female death, being more notable at those temperatures in which fertility was highest. This reduction in the number of parasitized eggs over the female longevity increased is typical in pro-ovigenic species as the parasitoids of the genus Trichogramma [27].

Emergence rate or viability of $T$. achaeae was relatively stable at all tested temperatures. The emergence rate values, except for those observed at $15{ }^{\circ} \mathrm{C}$, were always above $80 \%$, being the highest viability measured at $30^{\circ} \mathrm{C}(95.43 \%)$. These values are greater than the previous results found for T. achaeae in C. cephalonica eggs [51], indicating that the viability can be influenced by both host and temperature [72]. The reduction in the emergence rate recorded at the lowest temperature $\left(15^{\circ} \mathrm{C}\right)$ can be due to the high mortality in the immature stages [71]. A single parasitoid emerged per egg of E. kuehniella, however it was common to find up 2-3 emerging adults from C. chalcites eggs collected in banana crops $[18,21]$. These differences could be caused by the bigger size of $C$. chalcites eggs compared to E. kuehniella eggs and its nutritional quality for the parasitoid development [73]. Despite that, our findings clearly shown that E. kuehniella eggs can be considered an appropriate alternative host to support the development of T. achaeae. Temperature is also a strongly important factor in affecting the sex ratio in Trichogramma spp. [31,73]. However, the influence of temperature on the sex ratio differs according to the species/strain of Trichogramma [72]. In our study, temperature significantly modified the sex ratio of T. achaeae, being female biased between $15{ }^{\circ} \mathrm{C}$ and $25^{\circ} \mathrm{C}$, whereas it was balanced at $30^{\circ} \mathrm{C}$. Percentage of females fluctuated from 48.41 to 68.10 , which is coherent with Melo [76], who noticed that sex ratio was biased to female production at the same temperatures.

In accordance with our knowledge, no studies have been carried out before to determine the temperature influence on population parameters of T. achaeae. Two-sex life tables are a powerful instrument to describe the probable development of a species [61]. Results obtained in this work indicate that T. achaeae was able to quickly increase its populations in the temperature range of $15^{\circ} \mathrm{C}$ to $30^{\circ} \mathrm{C}$. Several authors have adopted fertility life tables for estimating potential of Trichogramma species or strains submitted to different factors such as temperature and host adaptability [31,78]. The present study reports significant variations in the two-sex life table parameters of T. achaeae in response to the distinct temperature tested. The net reproductive rate $\left(R_{0}\right)$ varied according to the temperature variation, from 14.08 to 32.00 offspring per individual. The highest increase in net reproductive rate was observed at $20^{\circ} \mathrm{C}$. The net reproductive rate was adversely influenced by temperatures below or above $20^{\circ} \mathrm{C}$, and therefore, the population growth capacity was particularly reduced. According to Cabello and Vargas [58], the diminution of the net reproductive rate at elevated temperatures may be due to the production of both males and females at these temperatures. Results also showed that intrinsic rate of increase $(r)$ and finite rate of increase $(\lambda)$ were proportionally related to temperature, increasing considerably until the highest temperature was reached, while the mean generation time $(T)$ was lowest at $30^{\circ} \mathrm{C}$. Therefore, our results indicated that E. kuehniella is an appropriate host for the mass rearing of T. achaeae, and they are in line with those reported by Varma and Maninder [50] and Manohar et al. [52] on C. cephalonica and T. absoluta eggs, respectively.

Therefore, the determination of the biological characteristics, thermal requirements and population parameters of T. achaeae on E. kuehniella eggs contributed essential information for the development of biological control programs, because the results demonstrated that this parasitoid species is able to survival and develop within the tested temperature range (from $15{ }^{\circ} \mathrm{C}$ to $30{ }^{\circ} \mathrm{C}$ ). In this sense, Cabello et al. [23] found that T. achaeae is a species well adapted to extreme temperature conditions in commercial tomato greenhouses in southern Spain. Our results would explain the presence of T. achaeae throughout the year in banana crops in the Canary Islands, both in mesh-built greenhouses and in open fields [21], where a Mediterranean-type climate is present and C. chalcites eggs are available for the parasitoid survival during all banana production cycle $[8,79,80]$. Thus, the thermal tolerance of T. achaeae in this study to both average minimum and maximum temperatures occurring in the Canary Islands $\left(16-27^{\circ} \mathrm{C}\right)$, make this species a suitable candidate as biocontrol agent of $C$. chalcites in 
banana groves [13]. However, extreme temperatures had a detrimental impact on the biology and parasitization rates of T. achaeae [56,76].

No experiments have been performed before to determine the relationship between host densities and functional response for T. achaeae at different temperatures. The current study revealed that temperature had a substantial effect on the functional response of the egg parasitoid. Several studies have observed that the functional response of Trichogramma could change from one type to another as temperature [47,81] and host typology change [49]. Besides, similar changes have also been reported in other parasitoid species [68]. According our results, T. achaeae showed a type I functional response at $15^{\circ} \mathrm{C}$. In this sense, Jeschke et al. [82] indicate that a type I response is attributable to the following two essential requisites: 1$)$ a very short handling time $\left(T_{h}\right)$ and 2$)$ a state of maximum activity at saturation. However, in laboratory conditions at $15{ }^{\circ} \mathrm{C}$, both requisites seem to be met for T. achaeae, who seems to have a very low $T_{h}$, and only ceases to lay eggs when the female reaches its eggs in the ovarioles. These findings agree with those seen for other Trichogramma and Trichogrammatoidea species, in which most cases present type I functional responses [42-46]. In the other hand, at $25{ }^{\circ} \mathrm{C}$ the functional response of T. achaeae is type II, which is influenced by the time of handling. Our results are in line with a type II functional response exhibited by T. achaeae to T. absoluta eggs [83]. However, it should be noted that, in a species of the genus, T. ostrinae, the functional response is type II but changes to type III when the temperature increases from $20^{\circ} \mathrm{C}$ to $27^{\circ} \mathrm{C}$ [47]. Besides temperature, another factor that seems to condition the type of functional response in parasitoids of the genus Trichogramma is the host species; thus T. pretiosum Riley parasitizing T. absoluta eggs presents a type I functional response [44], but when it parasitizes H. armigera eggs, the response is type II [81]. Also, T. chilonis Ishii that presents type II response in eggs from its natural host Chilo sacchariphagus (Bojer) changes to type III when offered eggs from its unnatural host Galleria mellonella L. [49]. On the other hand, the functional responses change to type II when T. achaeae females must parasitize previously parasitized eggs, which is an extremely common phenomenon under natural conditions.

\section{Conclusions}

This study is the first to report the effect of temperature on two-sex life table parameters and functional response of T. achaeae, an important parasitoid of T. absoluta and C. chalcites in the Paleartic region. The age-stage, two-sex life-table analysis obtained from this research has provided fundamental information on the effects of temperature on the developmental time, survivorship, reproduction, and longevity of T. achaeae. Results showed that temperature ranging from $15{ }^{\circ} \mathrm{C}$ to $30^{\circ} \mathrm{C}$ was favorable for its growth, development, and survival, as well as the adequacy of E. kuehniella eggs as alternative host in T. achaeae mass rearing systems. In addition, the results showed a clear relationship between temperature and the functional response of $T$. achaeae. Parasitoid female had a greater efficiency at $25^{\circ} \mathrm{C}$, showing a Holling type II functional response. The rate of parasitism increased when the host density increased. The present study can facilitate the optimization of laboratory conditions for the mass rearing of $T$. achaeae and present a starting point to enhance the biological control of several lepidopteran pest species.

Author Contributions: Conceptualization, M.d.P., E.H.S. and T.C.; methodology, M.d.P. and T.C.; software, M.d.P. and T.C.; validation, M.d.P., E.H.S. and T.C.; formal analysis, M.d.P., E.H.S. and T.C.; investigation, M.d.P., J.R.G., E.H.S. and T.C.; resources, M.d.P.; data curation, M.d.P. and J.R.G.; writing-original draft preparation, M.d.P., E.H.S. and T.C.; writing—review and editing, M.d.P., E.H.S. and T.C.; visualization, M.d.P.; supervision, M.d.P., E.H.S. and T.C.; project administration, E.H.S.; funding acquisition, E.H.S. All authors have read and agreed to the published version of the manuscript.

Funding: This work was financially supported by the Transnational Cooperation Program Madeira-Azores-Canary Islands (PCT MAC 2007-2013) (Project MAC/1/C054 BIOMUSA), 85\% co-financed by European Regional Development Fund (ERDF); and by AgroBio S.L.M. del Pino was financially supported by a pre-doctoral fellowship granted by Spanish National Institute for Agricultural and Food Research and Technology (INIA).

Acknowledgments: The authors are grateful to Romina Acosta for her technical assistance.

Conflicts of Interest: The authors declare no conflict of interest. 


\section{References}

1. Roques, A.; Auger-Rozenberg, M.A.; Blackburn, T.M.; Garnas, J.; Pyšek, P.; Rabitsch, W.; Richardson, D.M.; Wingfield, M.J.; Liebhold, A.M.; Duncan, R.P. Temporal and interspecific variation in rates of spread for insect species invading Europe during the last 200 years. Biol. Invasions 2016, 18, 907-920. [CrossRef]

2. Lopez-Vaamonde, C.; Agassiz, D.; Augustin, S.; De Prins, J.; De Prins, W.; De Prins, W.; Gomboc, S.; Ivinskis, P.; Karsholt, O.; Koutroumpas, A.; et al. Alien terrestrial arthropods of Europe. Lepidoptera. Chapter 11. BioRisk 2010, 4, 603-668. [CrossRef]

3. Desneux, N.; Wajnberg, E.; Wyckhuys, K.A.G.; Burgio, G.; Arpaia, S.; Narváez-Vasquez, C.A.; González-Cabrera, J.; Catalán-Ruescas, D.; Tabone, E.; Frandon, J.; et al. Biological invasion of European tomato crops by Tuta absoluta: Ecology, geographic expansion and prospects for biological control. J. Pest. Sci. 2010, 83, 197-215. [CrossRef]

4. Campos, M.R.; Biondi, A.; Adiga, A.; Guedes, R.N.C.; Desneux, N. From the Western Palaearctic region to beyond: Tuta absoluta 10 years after invading Europe. J. Pest Sci. 2017, 90, 787-796. [CrossRef]

5. Biondi, A.; Guedes, R.N.C.; Wan, F.H.; Desneux, N. Ecology, worldwide spread, and management of the invasive South American tomato pinworm, Tuta absoluta: Past, present, and future. Annu. Rev. Entomol. 2018, 63, 239-258. [CrossRef]

6. Sparks, T.H.; Dennis, R.L.H.; Croxton, P.J.; Cade, M. Increased migration of Lepidoptera linked to climate change. Eur. J. Entomol. 2007, 104, 139-143. [CrossRef]

7. Collins, L.; Korycinska, A.; Baker, R. Rapid Pest Risk Analysis for Crysodeixis chalcites. In Food and Environment Research Agency, United Kingdom; 2014. Available online: http://www.fera.defra.gov.uk/plants/plantHealth/ pestsDiseases/documents/chrysodeixisChalcites.pdf (accessed on 1 June 2020).

8. del Pino, M.; Cabello, T.; Hernández-Suárez, E. Age-Stage, Two-Sex Life Table of Chrysodeixis chalcites (Lepidoptera: Noctuidae) at constant temperatures on semi-synthetic diet. Environ. Entomol. 2020, nvaa050. [CrossRef]

9. Suckling, D.M.; Conlong, D.E.; Carpenter, J.E.; Bloem, K.A.; Rendon, P.; Vreysen, M.J.B. Global range expansion of pest Lepidoptera requires socially acceptable solutions. Biol. Invasions 2017, 19, 1107-1119. [CrossRef]

10. Campos, M.R.; Silva, T.B.M.; Silva, W.M.; Silva, J.E.; Siqueira, H.A.A. Spinosyn resistance in the tomato borer Tuta absoluta (Meyrick) (Lepidoptera: Gelechiidae). J. Pest Sci. 2015, 88, 405-412. [CrossRef]

11. Desneux, N.; Decourtye, A.; Delpuech, J.M. The sublethal effects of pesticides on beneficial arthropods. Annu. Rev. Entomol. 2007, 52, 81-106. [CrossRef] [PubMed]

12. Gallego, J.R.; Guerrero-Manzano, J.; Fernández-Maldonado, F.J.; Cabello, T. Susceptibility of the egg parasitoid Trichogramma achaeae (Hymenoptera: Trichogrammatidae) to selected insecticides used in tomato greenhouses. Spanish J. Agric. Res. 2019, 17, e1009. [CrossRef]

13. del Pino, M.; Carnero, A.; Hernández-Suárez, E.; Cabello, T. Bases para la gestión integrada de Chrysodeixis chalcites (Lep.: Noctuidae) en cultivos de platanera de Canarias. Phytoma 2015, 271, 40-46.

14. Smith, S.M. Biological control with Trichogramma: Advances, successes, and potential of their use. Annu. Rev. Entomol. 1996, 41, 375-406. [CrossRef] [PubMed]

15. Mills, N. Egg parasitoids in biological control and integrated pest management, Chapter 15. In Egg Parasitoids in Agroecosystems with Emphasis on Trichogramma; Consoli, F.L., Parra, J.R.P., Zucchi, R.A., Eds.; Springer: New York, NY, USA, 2010; pp. 389-412.

16. Wang, Z.Y.; He, K.L.; Zhang, F.; Lu, X.; Babendreier, D. Mass rearing and release of Trichogramma for biological control of insect pests of corn in China. Biol. Control 2014, 68, 136-144. [CrossRef]

17. Kumar, P.; Sekhar, J.C.; Kaur, J. Trichogrammatids: Integration with other methods of pest control. In Biological Control of Insect Pests Using Egg Parasitoids; Sithanantham, S., Ballal, C.R., Jalali, S.K., Bakthavatsalam, N., Eds.; Springer: New Delhi, India, 2013; pp. 191-208.

18. Polaszek, A.; Rugman-Jones, P.F.; Stouthamer, R.; Hernández-Suarez, E.; Cabello, T.; del Pino-Pérez, M. Molecular and morphological diagnoses of five species of Trichogramma: Biological control agents of Chrysodeixis chalcites (Lepidoptera: Noctuidae) and Tuta absoluta (Lepidoptera: Gelechiidae) in the Canary Islands. Biocontrol 2012, 57, 21-35. [CrossRef] 
19. Polaszek, A. Biodiversity and host associations of Trichogramma in Eurasia, Chapter 9. In Egg Parasitoids in Agroecosystems with Emphasis on Trichogramma; Consoli, F.L., Parra, J.R.P., Zucchi, R.A., Eds.; Springer: New York, NY, USA, 2010; pp. 237-266.

20. Wright, M.G.; Stouthamer, R. First report of Trichogramma achaeae (Hymenoptera: Trichogrammatidae) from Hawaii. Proc. Hawaii. Entomol. Soc. 2011, 43, 67.

21. del Pino, M.; Rugman-Jones, P.F.; Hernández-Suárez, E.; Polaszek, A.; Stouthamer, R. Rapid molecular identification of five species of Trichogramma occurring in the Canary Islands with notes on their distribution in banana groves. Biocontrol 2013, 58, 515-524. [CrossRef]

22. van Lenteren, J.C.; Bolckmans, K.; Kohl, J.; Ravensberg, W.J.; Urbaneja, A. Biological control using invertebrates and microorganisms: Plenty of new opportunities. BioControl 2018, 63, 39-59. [CrossRef]

23. Cabello, T.; Gallego, J.R.; Fernández, F.J.; Gámez, M.; Vila, E.; del Pino, M.; Hernández-Suárez, E. Biological control strategies for the south American tomato moth Tuta absoluta (Lepidoptera: Gelechiidae) in greenhouse tomatoes. J. Econ. Entomol. 2012, 105, 2085-2096. [CrossRef]

24. Chailleux, A.; Desneux, N.; Seguret, J.; Khanh, H.D.T.; Maignet, P.; Tabone, E. Assessing European egg parasitoids as a mean of controlling the invasive South American tomato pinworm Tuta absoluta. PLoS ONE 2012, 7, e48068. [CrossRef]

25. Giorgini, M.; Guerrieri, E.; Cascone, P.; Gontijo, L. Current strategies and future outlook for managing the neotropical tomato pest Tuta absoluta (Meyrick) in the Mediterranean basin. Neotrop. Entomol. 2019, 48, 1-17. [CrossRef]

26. Yadav, D.N. Egg parasitoids in cotton ecosystem. In Biological Control of Insect Pests Using Egg Parasitoids; Sithanantham, S., Ballal, C.R., Jalali, S.K., Bakthavatsalam, N., Eds.; Springer: New Delhi, India, 2013; pp. 301-315.

27. de Freitas Bueno, R.C.O.; Parra, J.R.P.; de Freitas Bueno, A. Trichogramma pretiosum parasitism of Pseudoplusia includens and Anticarsia gemmatalis eggs at different temperatures. Biol. Control 2012, 60, 154-162. [CrossRef]

28. Coelho, A.; Rugman-Jones, P.F.; Reigada, C.; Stouthamer, R.; Parra, J.R.P. Laboratory performance predicts the success of field releases in inbred lines of the egg parasitoid Trichogramma pretiosum (Hymenoptera: Trichogrammatidae). PLoS ONE 2016, 11, e0146153. [CrossRef] [PubMed]

29. de Oliveira, C.M.; de Oliveira, J.V.; Barbosa, D.R.S.; Breda, M.O.; de França, S.M.; Duarte, B.L.R. Biological parameters and thermal requirements of Trichogramma pretiosum for the management of the tomato fruit borer (Lepidoptera: Crambidae) in tomatoes. Crop Prot. 2017, 99, 39-44. [CrossRef]

30. Maceda, A.; Hohmann, C.L.; Santos, H.R. Temperature effects on Trichogramma pretiosum Riley and Trichogrammatoidea annulata De Santis. Brazilian Arch. Biol. Technol. 2003, 46, 27-32. [CrossRef]

31. Pratissoli, D.; Parra, J.R.P. Fertility life table of Trichogramma pretiosum (Hym., Trichogrammatidae) in eggs of Tuta absoluta and Phthorimaea operculella (Lep., Gelechiidae) at different temperatures. J. Appl. Entomol. 2000, 124, 339-342. [CrossRef]

32. Andrade, G.S.; Pratissoli, D.; Dalvi, L.P.; Desneux, N.; dos Santos, H.J.G. Performance of four Trichogramma species (Hymenoptera: Trichogrammatidae) as biocontrol agents of Heliothis virescens (Lepidoptera: Noctuidae) under various temperature regimes. J. Pest Sci. 2011, 84, 313-320. [CrossRef]

33. Parra, J.R.P. Egg Parasitoids Commercialization in the New World. Chapter 14. In Egg Parasitoids in Agroecosystems with Emphasis on Trichogramma; Consoli, F.L., Parra, J.R.P., Zucchi, R.A., Eds.; Springer: New York, NY, USA, 2010; pp. 373-388.

34. Schöller, M.; Hassan, S.A. Comparative biology and life tables of Trichogramma evanescens and T. cacoeciae with Ephestia elutella as host at four constant temperatures. Entomol. Exp. Appl. 2001, 98, 35-40. [CrossRef]

35. Foerster, M.R.; Foerster, L.A. Effects of temperature on the immature development and emergence of five species of Trichogramma. Biocontrol 2009, 54, 445-450. [CrossRef]

36. Özder, N.; Kara, G. Comparative biology and life tables of Trichogramma cacoeciae, T. brassicae and T. evanescens (Hymenoptera: Trichogrammatidae) with Ephestia kuehniella and Cadra cautella (Lepidoptera: Pyralidae) as hosts at three constant temperatures. Biocontrol Sci. Technol. 2010, 20, 245-255. [CrossRef]

37. Berryman, A.A. The theoretical foundations of biological control. In Theoretical Approaches to Biological Control; Hawkins, B.A., Cornell, H.V., Eds.; Cambridge University Press: Cambridge, UK, 1999; pp. 3-21.

38. Solomon, M.E. The natural control of animal populations. J. Anim. Ecol. 1949, 18, 1-35. [CrossRef] 
39. Oaten, A.; Murdoch, W.W. Functional response and stability in predator-prey systems. Am. Nat. 1975, 109, 289-298. [CrossRef]

40. Holling, C.S. The components of predation as revealed by a study of small-mammal predation of the European pine sawfly. Can. Entom. 1959, 91, 293-320. [CrossRef]

41. Hassell, M.P. The Spatial and Temporal Dynamics of Insect Host-Parasitoid Interactions; Oxford University Press: Oxford, UK, 2000.

42. Mills, N.J.; Lacan, I. Ratio dependence in the functional response of insect parasitoids: Evidence from Trichogramma minutum foraging for eggs in small host patches. Ecol. Entomol. 2004, 29, 208-216. [CrossRef]

43. Cabello, T.; Vargas, P. Response of Trichogramma cordubensis and T. pintoi to different densities of alternative host eggs. Les Colloques de l'INRA 1988, 9, 165-172.

44. Faria, C.A.; Torres, J.B.; Farias, A.M.I. Resposta funcional de Trichogramma pretiosum Riley (Hymenoptera: Trichogrammatidae) parasitando ovos de Tuta absoluta (Meyrick) (Lepidoptera: Gelechiidae): Efeito da idade do hospedeiro. An. Soc. Entomológica Bras. 2000, 29, 85-93. [CrossRef]

45. Kalyebia, A.; Overholtb, W.A.; Schulthessa, F.; Muekec, J.M.; Hassan, S.A.; Sithananthama, S. Functional response of six indigenous trichogrammatid egg parasitoids in Kenya: Influence of temperature and relative humidity. Biol. Control 2005, 32, 164-171. [CrossRef]

46. Cabello, T.; Gámez, M.; Torres, A.; Garay, J. Possible effects of inter-specific competition on the coexistence of two parasitoid species: Trichogramma brassicae Bezdenko and Chelonus oculator (F.) (Hymenoptera: Trichogrammatidae, Braconidae). Community Ecol. 2011, 12, 78-88. [CrossRef]

47. Wang, B.; Ferro, D.N. Functional responses of Trichogramma ostriniae to Ostrinia nubilalis under laboratory and field conditions. Environ. Entomol. 1998, 27, 752-758. [CrossRef]

48. Moezipour, M.; Kafil, M.; Allahyari, H. Functional response of Trichogramma brassicae at different temperatures and relative humidities. Bull. Insectol. 2008, 61, 245-250.

49. Reay-Jones, F.P.F.; Rochat, J.; Goebel, R.; Tabone, E. Functional response of Trichogramma chilonis to Galleria mellonella and Chilo sacchariphagus eggs. Entomol. Exp. Appl. 2006, 118, 229-236. [CrossRef]

50. Varma, G.C. Growth of population of Trichogramma achaeae Nagaraja and Nagarkatti (Trichogrammatidae: Hymenoptera). J. Res.-Punjab Agric. Univ. 1981, 18, 101-103.

51. Ghosh, E.; Ballal, C.R.; Verghese, A. Temperature based differences in biological parameters of some potential species/strains of Trichogramma. J. Biol. Control 2017, 31, 82-89. [CrossRef]

52. Manohar, T.N.; Sharma, P.L.; Verma, S.C.; Chandel, R.S. Demographic parameters of the indigenous egg parasitoids, Trichogramma spp., parasitizing the invasive tomato leafminer, Tuta absoluta (Meyrick) (Lepidoptera: Gelechiidae). Egypt J. Biol. Pest Control 2019, 29, 1-9. [CrossRef]

53. Jalali, S.K.; Singh, S.P. Differential response of four Trichogramma species to low temperatures for short term storage. Entomophaga 1992, 37, 159-165. [CrossRef]

54. Singhamuni, S.A.A.; Hemachandra, K.S.; Sirisena, U.G.A.I. Potential for mass rearing of the egg parasitoids, Trichogramma chilonis and Tricogramma achaeae (Hymenoptera: Trichogrammatidae) on Corcyra cephalonica eggs. Trop. Agric. Res. 2016, 27, 1-12. [CrossRef]

55. Ghosh, E.; Ballal, C.R. Short-term storage of the egg parasitoids, Trichogramma and Trichogrammatoidea. Egypt J. Biol. Pest Control 2018, 28, 34. [CrossRef]

56. Cascone, P.; Carpenito, S.; Slotsbo, S.; Iodice, L.; Givskov, J.; Holmstrup, M.; Guerrieri, E. Improving the efficiency of Trichogramma achaeae to control Tuta absoluta. BioControl 2015, 60, 761-771. [CrossRef]

57. Cerutti, F.; Bigler, F.; Eden, G.; Bosshart, S. Optimal larval density and quality control aspects in mass rearing of the Mediterranean flour moth, Ephestia kuehniella Zell. (Lep.: Phycitidae). J. Appl. Entomol. 1992, 114, 353-361. [CrossRef]

58. Cabello, T.; Vargas, P. The effect of temperature on the bionomic of Trichogramma cordubensis Vargas and Cabello (Hym.: Trichogrammatidae). In Trichogramma and Other Egg Parasites; Voegele, J., Waage, J., van Lenteren, J., Eds.; I.N.R.A. Pub.: Paris, France, 1988; pp. 155-164.

59. IBM. IBM SPSS Statistics for Windows, Version 22.0; IBM Corp.: Armonk, NY, USA, 2013.

60. Ikemoto, T.; Takai, K. A new linearized formula for the law of total effective temperature and the evaluation of line fitting methods with both variables subject to error. Environ. Entomol. 2000, 29, 671-682. [CrossRef]

61. Chi, H.; Liu, H. Two new methods for the study of insect population ecology. Bull. Inst. Zool. Acad. Sin. $1985,24,225-240$. 
62. Chi, H. Life-table analysis incorporating both sexes and variable development rates among individuals. Environ. Entomol. 1988, 17, 26-34. [CrossRef]

63. Chi, H. TWOSEX-MSChart: Computer Program for Age Stage, Two-Sex Life Table Analysis; Laboratory of Theoretical Ecology: Taichung, Taiwan, 2013; Available online: http://140.120.197.173/ecology/ (accessed on 1 June 2020).

64. Goodman, D. Optimal life histories, optimal notation, and the value of reproductive value. Am. Nat. 1982, 119, 803-823. [CrossRef]

65. Efron, B.; Tibshirani, R.J. An Introduction to the Bootstrap; Chapman \& Hall: New York, NY, USA, 1993.

66. Huang, Y.B.; Chi, H. Age-stage, two-sex life tables of Bactrocera cucurbitae (Coquillett) (Diptera: Tephritidae) with a discussion on the problem of applying female age-specific life tables to insect populations. Insect Sci. 2012, 19, 263-273. [CrossRef]

67. Cabello, T.; Gámez, M.; Varga, Z. An improvement of the holling type III functional response in entomophagous species model. J. Biol. Syst. 2007, 15, 515-524. [CrossRef]

68. García-Martin, M.; Gámez, M.; Torres-Ruiz, A.; Cabello, T. Functional response of Chelonus oculator according to temperature. Community Ecol. 2008, 9, 45-51. [CrossRef]

69. Jandel Scientific. Table Curve 2D-User's manual. Version 2.0; Jandel Scientific: San Rafael, CA, USA, 1994.

70. Motulsky, H.; Christopoulos, A. Fitting Models to Biological Data Using Linear and Nonlinear Regression: A Practical Guide to Curve Fitting; GraphPad Software Inc.: San Diego, CA, USA, 2003.

71. Samara, R.; Monje, J.C.; Zebitz, C.P.W.; Qubbaj, T. Comparative biology and life tables of Trichogramma aurosum on Cydia pomonella at constant temperatures. Phytoparasitica 2011, 39, 109-119. [CrossRef]

72. Bueno, R.C.O.d.F.; Parra, J.R.P.; Bueno, A.D.F. Biological characteristics and thermal requirements of a Brazilian strain of the parasitoid Trichogramma pretiosum reared on eggs of Pseudoplusia includens and Anticarsia gemmatalis. Biol. Control 2009, 51, 355-361. [CrossRef]

73. Altoé, T.; Pratissoli, D.; De Carvalho, J.R.; Dos Santos, H.J.G.; Paes, J.P.P.; Bueno, R.C.O.D.F.; Bueno, A.D.F. Trichogramma pretiosum (Hymenoptera: Trichogrammatidae) parasitism of Trichoplusia ni (Lepidoptera: Noctuidae) eggs under different temperatures. Ann. Entomol. Soc. Am. 2012, 105, 82-89. [CrossRef]

74. Kishani Farahani, H.; Ashouri, A.; Zibaee, A.; Abroon, P.; Alford, L. The effect of host nutritional quality on multiple components of Trichogramma brassicae fitness. Bull. Entomol. Res. 2016, 106, 633-641. [CrossRef]

75. Foerster, M.R.; Marchioro, C.A.; Foerster, L.A. Temperature dependent parasitism, survival, and longevity of five species of Trichogramma Westwood (Hymenoptera: Trichogrammatidae) associated with Anticarsia gemmatalis Hübner (Lepidoptera: Noctuidae). Neotrop. Entomol. 2014, 43, 176-182. [CrossRef] [PubMed]

76. Melo, M.J.L.A.L. Dynamics Study and Temperature Effect on Biological Traits of TWO TRICHOGRAMMA SPECIES (Hymenoptera, Trichogrammatidae) of S. Miguel Island. Master's Thesis, Universidade dos Açores, Açores, Portugal, 2011.

77. Mashal, S.; Agamy, E.; Abou-bakr, H.; El-Wahab, T.E.A.; El Behery, H. Effect of honeybee products, as food supplements, on the biological activities of three Trichogramma species (Hymenoptera: Trichogrammatidae). Egypt J. Biol. Pest Control 2019, 29, 46. [CrossRef]

78. Pratissoli, D.; Fernandes, O.A.; Zanuncio, J.C.; Pastori, P.L. Fertility life table of Trichogramma pretiosum and Trichogramma acacioi (Hymenoptera: Trichogrammatidae) on Sitotroga cerealella (Lepidoptera: Gelechiidae) eggs at different constant temperatures. Ann. Entomol. Soc. Am. 2004, 97, 729-731. [CrossRef]

79. Cakmak, T.; Piedra-Buena, A.; Hernández-Suárez, E.; Alvarez-Acosta, C. Chrysodeixis chalcites (Esper) (Lepidoptera: Noctuidae) oviposition preferences on different growing stages of banana (Musa acuminate Colla, Musaceae) plants. Phytoparasitica 2019, 47, 485-498. [CrossRef]

80. Fuentes, E.G.; Hernández-Suárez, E.; Simón, O.; Williams, T.; Caballero, P. Chrysodeixis chalcites, a pest of banana crops on the Canary Islands: Incidence, economic losses and current control measures. Crop Prot. 2018, 108, 137-145. [CrossRef]

81. Kfir, R. Functional response to host density by the egg parasite Trichogramma Pretiosum. Entomophaga 1983, 28, 345-353. [CrossRef] 
82. Jeschke, J.M.; Kopp, M.; Tollrian, R. Consumer-food systems: Why type I functional responses are exclusive to filter feeders. Biol. Rev. 2004, 79, 337-349. [CrossRef]

83. Manohar, T.N.; Sharma, P.L.; Verma, S.C.; Sharma, K.C.; Chandel, R.S. Functional response of indigenous Trichogramma spp. to invasive tomato leafminer, Tuta absoluta (Meyrick) under laboratory conditions. Int. J. Trop. Insect Sci. 2020, 40, 101-107. [CrossRef] 